\title{
Is success hereditary? Evidence on the performance of spawned ventures
}

Citation for published version (APA):

Dick, J., Hussinger, K., Blumberg, B. F., \& Hagedoorn, J. (2011). Is success hereditary? Evidence on the performance of spawned ventures. METEOR, Maastricht University School of Business and Economics. METEOR Research Memorandum No. 034 https://doi.org/10.26481/umamet.2011034

Document status and date:

Published: 01/01/2011

DOI:

10.26481/umamet.2011034

Document Version:

Publisher's PDF, also known as Version of record

\section{Please check the document version of this publication:}

- A submitted manuscript is the version of the article upon submission and before peer-review. There can be important differences between the submitted version and the official published version of record.

People interested in the research are advised to contact the author for the final version of the publication, or visit the DOI to the publisher's website.

- The final author version and the galley proof are versions of the publication after peer review.

- The final published version features the final layout of the paper including the volume, issue and page numbers.

Link to publication

\footnotetext{
General rights Owners
rights.

- You may freely distribute the URL identifying the publication in the public portal. please follow below link for the End User Agreement:

www.umlib.nl/taverne-license

Take down policy

If you believe that this document breaches copyright please contact us at:

repository@maastrichtuniversity.nl

providing details and we will investigate your claim.
}

Copyright and moral rights for the publications made accessible in the public portal are retained by the authors and/or other copyright owners and it is a condition of accessing publications that users recognise and abide by the legal requirements associated with these

- Users may download and print one copy of any publication from the public portal for the purpose of private study or research.

- You may not further distribute the material or use it for any profit-making activity or commercial gain

If the publication is distributed under the terms of Article $25 \mathrm{fa}$ of the Dutch Copyright Act, indicated by the "Taverne" license above, 


\section{Maastricht University}

Johannes Dick, Katrin Hussinger, Boris Blumberg, John Hagedoorn

I s success hereditary? Evidence on the performance of spawned ventures

$\mathrm{RM} / 11 / 034$

\section{METEOR}

Maastricht University School of Business and Economics

Maastricht Research School of Economics

of Technology and Organization

P.O. Box 616

NL - 6200 MD Maastricht

The Netherlands 


\title{
Is Success Hereditary? Evidence on the Performance of Spawned Ventures
}

\author{
Johannes M.H. Dick ${ }^{\mathrm{a}}$, Katrin Hussinger ${ }^{\mathrm{a}}$, Boris Blumberg ${ }^{\mathrm{a}}$ and John Hagedoorn ${ }^{\mathrm{a}}$ \\ ${ }^{a}$ Maastricht University, Dept. of Organization and Strategy (The Netherlands)
}

January 2011

\begin{abstract}
A common phenomenon in entrepreneurship is that employees turn away from employment to found their own businesses. Prior literature discusses the former employers' characteristics that influence the creation of entrepreneurial ventures. An investigation of whether these characteristics also affect the success of the spawned ventures is missing so far. This paper contributes to the literature by showing that entrepreneurial ventures spawned by well performing firms are financially more successful than ventures stemming from bad performing firms. This suggests that spawned entrepreneurs are able to exploit valuable knowledge from their previous employers which impacts their ventures' performance positively. The analysis is based on a linked employee-employer dataset for the Netherlands for the period 1999-2004.
\end{abstract}

Keywords: entrepreneurship; entrepreneurial spawning; start-ups; firm performance JEL-Classification: L26, M13, L25

\section{Contact:}

Johannes Dick, Maastricht University, Dept. of Organization and Strategy, Tongersestraat 53, 6211 LM Maastricht, The Netherlands

E-Mail: j.dick@maastrichtuniversity.nl; Phone: +31 (0) 4338 83897; Fax:+31(0) 433884893

Katrin Hussinger, Maastricht University, Dept. of Organization and Strategy, Tongersestraat 53, 6211 LM Maastricht, The Netherlands

E-Mail: k.hussinger@maastrichtuniversity.nl; Phone: +31 (0) 4338 84943; Fax: +31(0) 433884893

Boris Blumberg, Maastricht University, Dept. of Organization and Strategy,

Tongersestraat 53, 6211 LM Maastricht, The Netherlands

E-Mail: b.blumberg@maastrichtuniversity.nl; Phone: +31 (0) 4338 83639; Fax: +31(0) 433884893

John Hagedoorn, Maastricht University, Dept. of Organization and Strategy,

Tongersestraat 53, 6211 LM Maastricht, The Netherlands

E-Mail: j.hagedoorn@maastrichtuniversity.nl; Phone: +31 (0) 4338 83667; Fax: +31(0) 433884893 


\section{Introduction}

The public image of entrepreneurship is shaped by talented individuals who lack education and work experience but still manage to found highly successful and worldrenowned companies (Chatterij, 2009). Famous examples include Bill Gates, Steve Jobs and Sir Richard Branson who have all become self-made billionaires (Miller and Kroll, 2010). The more realistic view on entrepreneurship, however, is that entrepreneurs display significant employment histories (Cooper, 1985; Chandler, 1996). In fact, several academic studies argue that many entrepreneurs make use of business ideas that have been encountered through previous employment (Klepper, 2001; Agarwal et al., 2004; Klepper and Sleeper, 2005; Cassiman and Ueda, 2006; Hyytinen and Maliranta, 2008). ${ }^{1}$

Accordingly, existing firms seem to be an important driving force of entrepreneurship as many new ventures are bred by their founders' previous employers. This process, by which former employees create new, independent ventures, is referred to as "entrepreneurial spawning". Although entrepreneurial spawning appears to be a rather common and acknowledged phenomenon (Gompers et al., 2005; Klepper and Sleeper, 2005; Garvin, 1983; Cooper, 1985), only a few studies analyze the characteristics of firms that spawn entrepreneurial ventures (Gompers et al., 2005; Hyytinen and Maliranta, 2008; Elfenbein et al., 2010). Rather prominent themes within these studies deal with the impact of firm size and performance on the rate at which new ventures are spawned (Gompers et al., 2005; Hyytinen and Maliranta, 2008; Franco and Filson, 2006; Elfenbein et al., 2010). Especially large firms are often argued to have high spawning rates. An explanation could be that employees start new ventures because they become frustrated that the entrepreneurial opportunities they identify are constantly rejected by their employers (Gompers et al., 2005). Small firms, in contrast, are assumed to equip their employees with the necessary skills for founding new

\footnotetext{
${ }^{1}$ This view has been confirmed in interviews with 100 founders of fast growing companies (Bhidé, 1994). 71\% of these founders admitted that they took advantage of a business idea they had come across at their previous employer.
} 
ventures which is reflected in increased spawning rates (Elfenbein et al., 2010). Regarding firm performance, two opposing views can be brought forward as well. Whereas less successful firms could spawn more new ventures because the opportunity costs for employees to stay at the firm are low, well performing firms might have high spawning rates as employees become exposed to more entrepreneurial opportunities (Gompers et al., 2005).

A shortcoming in the current literature on entrepreneurial spawning, however, is that the link between the characteristics of the spawning firms (the former employers) and the success of the newly spawned ventures is insufficiently discussed (Gompers et al., 2005; Cassiman and Ueda, 2006; Klepper and Thompson, 2010). Of particular interest is the question whether successful firms also spawn successful ventures. It can be assumed that better performing firms provide an excellent learning environment for their employees, resulting in the creation of more successful ventures (Klepper, 2007; Boschma and Wenting, 2007). In this paper, we address this gap in the entrepreneurship literature and scrutinize if a positive relationship between venture performance and spawning firm performance exists.

Our empirical analysis is based on the official employee-employer data sets of Statistics Netherlands for the years 1999-2005. As a first step of our analysis, we explore the effect of firm size and performance on the rate at which new ventures are spawned. Our results for the Netherlands largely confirm the findings by a previous study for the U.S. (Gompers et al., 2005) as we show that large firms are the most active spawners. Furthermore, financially successful firms are found to spawn fewer ventures than unsuccessful firms. In the second step, we investigate if the spawning firms' characteristics have an effect on the ventures' performance. We find that being spawned by successful firms has a positive impact on the financial performance of the new ventures. This suggests that venture founders who worked at well performing firms have gathered more valuable knowledge about founding and running new businesses successfully than founders previously employed by less successful companies. 
Our analysis contributes to the literature on entrepreneurial spawning in the following ways: to our knowledge, we are the first to study the effect of the spawning firms' characteristics on the ventures' financial performance. ${ }^{2}$ Second, our dataset encompasses a broad variety of spawning firms and newly spawned ventures. This means that our data is neither restricted to publicly listed spawning firms nor to newly spawned ventures that are venture capital backed (cf. Gompers et al., 2005). The dataset further covers entrepreneurial spawning in all manufacturing and service industries so that our study is not limited to one specific industry sector as in Agarwal et al. (2004) or Klepper and Sleeper (2005).

The remainder of the paper is organized as follows. In the next section, the existing literature on entrepreneurial spawning is reviewed. Afterwards, we describe our dataset and present the econometric results. The final section concludes.

\section{Theory and Research Questions}

Since entrepreneurial spawning has received increasing attention in the academic literature, scholars became interested in the characteristics of firms that breed new ventures. Two recurring characteristics within most studies are firm size and firm performance (Gompers et al., 2005; Hyytinen and Maliranta, 2008; Elfenbein et al., 2010). Up until now, however, the empirical findings vary across different industry sectors and countries. Whereas some studies observe a negative relationship between firm size and spawning rate (Hyytinen and Maliranta, 2008; Elfenbein et al., 2010), Gompers et al. (2005) report a positive relationship. Ambiguous findings also exist for the implications of performance on the rate at which new ventures are spawned. Gompers et al. (2005) discover that less successful firms spawn more ventures whereas Franco and Filson (2006) find no significant result. Previous literature provides theoretical arguments for these different empirical results.

\footnotetext{
${ }^{2}$ There are only two previous studies investigating the link between venture performance and the characteristics of the spawning companies (Franco and Filson, 2006; Erikkson and Kuhn 2006). Both studies, however, employ a survival based performance measure, while we focus on the ventures' financial performance.
} 
Large and bureaucratic firms are often argued to feature high spawning rates for a variety of reasons. Gompers et al. (2005) summarize these reasons and refer to them as the "Xerox view"3 of entrepreneurial spawning. First of all, unlike industry entrants, incumbent companies may be unable to adapt to radical technological change because their existing capabilities and routines are too inflexible (Tripsas and Gavetti, 2000; Sull, 1999; Tushman and Anderson, 1986). Henderson (1993) shows in her study on the photolithographic industry that incumbent firms are less productive than industry entrants at introducing radical technologies because of their outdated organizational capabilities. Such circumstances can induce creative and entrepreneurial employees to leave the firm and start their own ventures, where they can freely implement new ideas. A second reason for high spawning rates within large companies is that managers are incapable of evaluating and implementing entrepreneurial opportunities - as identified by employees - that are not within the firms' core lines of business (Gompers et al., 2005; Klepper and Sleeper, 2005). Because managers lack the knowledge to make an informed decision about an unrelated entrepreneurial opportunity, they tend to dismiss it. Similarly, established companies could make a deliberate choice to leave out on entrepreneurial opportunities which are not in line with their core competencies. In this case, the decision to neglect employees' entrepreneurial opportunities is not driven by organizational inefficiencies but by the conviction that remaining a focused firm is more value enhancing than being a diversified firm (Berger and Ofek, 1995). Accordingly, incumbents can act quite rigidly as they purposely forego profitable entrepreneurial opportunities for reasons of strategic commitment (Hellmann, 2007). All arguments of the Xerox view suggest that employees start new ventures because they are frustrated that the entrepreneurial opportunities they identified are not capitalized on by their employers (Gompers et al., 2005; Hellmann, 2007; Garvin, 1983; Klepper, 2001).

\footnotetext{
${ }^{3}$ Gompers et al. (2005) term this view the Xerox view because Xerox is exemplary for a large, incumbent firm that had to deal with the departure of several employees, who founded their own ventures.
} 
But not only large firms are considered as potential incubators for entrepreneurial ventures. Some studies report a negative relationship between firm size and spawning rate (Dobrev and Barnett, 2005; Elfenbein et al., 2010; Sørensen, 2007). Small firms can be active spawners because employees benefit from essential information on how to found new businesses. Relative to employees of large firms employees of small firms are granted superior access to valuable outside networks with customers and suppliers (Elfenbein et al., 2010; Wagner, 2004; Eriksson and Kuhn, 2006). Such network ties can be particularly useful when starting entrepreneurial ventures. Employees of small firms are also not bound to specialize on a single task. Instead, they can develop skills in a vast range of business related activities (Dobrev and Barnett, 2005; Elfenbein et al., 2010, Cooper, 1985). Lazear (2004, 2005) argues that successful entrepreneurs need to be "jacks-of-all-trades" and possess a balanced set of skills. Hence, small firms seem to provide the perfect organizational environment for employees to develop such sets of diversified skills, leading to higher rates of entrepreneurial spawning (cf. Sørensen, 2007; Elfenbein et al., 2010). The reasons presented above suggest that small firms shape their employees and provide them with the necessary skills, knowledge and contacts that could drive them into entrepreneurship eventually (Elfenbein et al., 2010).

It is also possible though that small firms breed new ventures because risk seeking individuals tend to self-select into such firms (Gompers et al., 2005; Sørensen, 2007). Working for smaller firms is risky since, compared to large firms, wages are more variable (Parker, 2006; Elfenbein et al., 2010) and the likelihood of firm exits in the first years is high (Wagner, 1994). There is evidence that less risk averse people start working in small companies and do not hesitate to turn to entrepreneurship once they spot a valuable business opportunity (Elfenbein et al., 2010). Accordingly, individuals preferring to work for small firms might be those with a preference for becoming self-employed all along. A final reason is related to the salaries paid in small firms. Usually, employees in small firms receive lower 
salaries than individuals working for larger companies (see Elfenbein et al., 2010, and the references therein). Consequently, the opportunity costs for leaving the employer and founding a new venture are significantly lower.

Based on these two perspectives it becomes obvious that the theoretical literature as well as the empirical evidence lack a clear standpoint whether a positive or negative relationship between size and spawning rate exists. On the one hand, employees of large firms could start new ventures because they are frustrated that the entrepreneurial opportunities they would like to pursue are hardly implemented by their employers. On the other hand, employees of small firms could become entrepreneurs because they have gathered the necessary know-how from their previous employers. Hence, the following research question arises:

RQ1: $\quad$ What effect does firm size have on the rate at which new ventures are spawned?

In a similar vein, the theoretical arguments for the relationship between employer performance and spawning rate are ambiguous. Irrespective of the employer's size, the employee's opportunity costs for starting a new venture are also low if the performance of the employer is weak. Most empirical studies confirm that employees who work at an unsuccessful firm turn to entrepreneurship because the rents from remaining employed are small (Gompers et al., 2005; Hyytinen and Maliranta, 2008). Eriksson and Kuhn (2006) characterize ventures emerging from unsuccessful firms to be "pushed" as they are a reaction to unfavorable conditions at the spawning firms.

Alternatively, a firm could spawn more entrepreneurial ventures if its performance is high. This argument is based on the fact that employees working at a financially viable firm are assumed to be exposed to more entrepreneurial opportunities (Gompers et al., 2005; Franco and Filson, 2006), which they could pursue as self-employed individuals. Such 
ventures are "pulled" by the market as employees would only leave a profitable firm if the returns from the perceived entrepreneurial opportunity are high enough (Eriksson and Kuhn, 2006).

Since existing research suggests that the relationship between firm performance and spawning rate could either be positive or negative, the second research question reads as follows:

RQ2: $\quad$ What effect does firm performance have on the rate at which new ventures are spawned?

As previous literature mainly focuses on the determinants of entrepreneurial spawning, Gompers et al. (2005) suggest examining whether the spawning firms' characteristics can affect the success of the new ventures. In particular, they probe the question if ventures of successful spawning companies turn out to be successful as well. This positive relationship could be based on the quality of knowledge that founders of newly spawned ventures have learnt from their previous employers. Previous research has shown that nascent entrepreneurs can acquire useful knowledge about technologies (Klepper and Sleeper, 2005; Agarwal et al., 2004), markets (Jovanovic, 1982; Agarwal et al., 2004) and organizational processes (Buenstorf, 2009) during their employment phases. Since successful companies have accumulated a rich knowledge base (Klepper and Sleeper, 2005; Klepper, 2001), it can be assumed that ventures originating from such firms have superior initial knowledge endowments as compared to ventures of less successful spawning companies. In other words, depending on their origin, some ventures have a knowledge advantage at birth, which can have long lasting effects on their performance (Agarwal et al., 2004; Chatterij, 2009; Klepper and Sleeper, 2005; Stinchcombe, 1965). This implies that ventures which have been spawned by successful companies are likely to be successful themselves (cf. Klepper and Thompson, 
2006; Klepper, 2001; Cassiman and Ueda, 2006). In addition to the learning argument, ventures spawned by successful firms turn out to be successful because, as was described before, employees are only tempted to become entrepreneurs if the perceived entrepreneurial opportunity is of high quality and promises high returns (Erikkson and Kuhn, 2006).

So far, the only empirical evidence on the relationship between the performance of former employers and spawned ventures is provided by Franco and Filson (2006) and Erikkson and Kuhn (2006). Using data from the disk drive industry, Franco and Filson (2006) conclude that ventures of successful spawning companies turn out to be successful as well. Instead of using financial measures, however, they rely on the ventures' life span to approximate performance. Erikkson and Kuhn (2006) conduct a similar analysis and find that ventures of firms which stopped their operations have lower survival probabilities than ventures of "healthy" firms. A drawback of survival measures is that they assume a strong correlation between economic performance and survival. Gimeno et al. (1997) argue, however, that performance is not the sole determinant of survival. Firms' own performance thresholds matter as well, which explains why only some underperforming firms cease to exist while others survive. All previous studies dealing with the relationship between venture performance and spawning firm performance are subject to this limitation (Franco and Filson, 2006; Erikkson and Kuhn, 2006). This paper circumvents this limitation by employing financial performance measures to analyze if there is a positive relationship between spawning firm success and venture success. Therefore, the final research question reads as follows:

RQ3: $\quad$ Is there a positive relationship between the financial performance of the spawning firm and the financial performance of the venture? 


\section{Data}

The empirical analysis relies on data sets provided by Statistics Netherlands (Centraal Bureau voor de Statistiek). Statistics Netherlands offers a rich set of information as it stores a variety of administrative registers, like employment statistics, self-employment statistics, financial statements for large and small firms and detailed firm level information (including firm location and firm age) for all firms in the Netherlands. All of these datasets contain unique employer and employee identifiers so that they can be linked to each other.

In order to answer our three research questions we construct two datasets. By means of the first database, we investigate the firm attributes affecting spawning rates. Hence, this database constitutes a sample of spawning firms and a control group of non-spawning firms. The second database is required to analyze if the ventures' performance is influenced by the characteristics of their spawning firms. The unit of analysis is therefore the spawned venture. The next two subsections describe in detail how both databases were compiled.

\subsection{Database 1: The Spawner Dataset}

Statistics Netherlands keeps track of the whole working population of the Netherlands. They not only observe individuals who are employed at companies but also hold information on self-employed individuals. The unit of observation in both data sources is the individual who can be linked to the company for which she works or, in case of self-employment, the venture she owns. Merging both datasets allows us to identify individuals who have been employed and then left their employers to start spawned ventures. ${ }^{4}$ By means of this information on the level of the individual, we identify the aggregate number of ventures a

\footnotetext{
${ }^{4}$ We allow for a gap of one year between employment and self-employment. This accounts for the fact that the transition process from employment to self-employment is not always smooth. It seems improbable that an employee quits her job in one month and has her own venture in the same or the following month already. Furthermore, our database only contains of first time entrepreneurs. Serial entrepreneurs have been eliminated, which is consistent with Gompers et al. (2005).
} 
particular employer has spawned per year. ${ }^{5}$ We can then relate these annual spawning levels to a set of detailed firm level characteristics from the General Business Register and the financial statements provided by Statistics Netherlands.

We restrict our sample to spawning firms from manufacturing and service industries. Furthermore, we exclude firms from the construction sector as this industry displays an unusually high rate of newly spawned ventures. A likely explanation is that the Dutch construction sector is characterized by "bogus self-employment", which means that contractors disguise their workers' employment status as self-employed (Vandenheuvel and Wooden, 1997). The contractors benefit financially from this as they become exempted from paying national insurance contributions for their workers.

In total, we identify 19,895 spawning firms that have spawned 26,010 ventures during the period 1999 to $2004 .{ }^{6}$ Since we want to scrutinize if certain firm characteristics (firm size and performance, in particular) increase the rates at which new ventures are spawned and the likelihood of spawning at the firm level, we drew a random sample of non-spawning firms. ${ }^{7}$ This control group of non-spawning companies contains of 28,320 firms. In total, the dataset contains of 122,272 firm year observations of Dutch manufacturing and service firms. 43\% $(52,597)$ of these observations are spawning firms in the sense that they have spawned at least one venture in the period from 1999-2004.

The following subsections describe the variables that are used for the empirical analysis and provide descriptive statistics for spawners and non-spawners.

\footnotetext{
${ }^{5}$ We define a spawning company as the last employer an entrepreneur has worked for although she could have had multiple previous jobs. This definition is also consistent with Gompers et al. (2005).

${ }^{6} \mathrm{We}$ can only analyze spawning rates in this time frame since the self-employment statistics and the employment statistics are unavailable before 1999.

${ }^{7}$ Firms in the control group did not engage in entrepreneurial spawning during the whole period of interest.
} 


\subsubsection{Variables: The Spawner Dataset}

As indicated above, the dependent variable of our analysis is the annual number of ventures that an employer has spawned (Spawning Rate).

Our main independent variables are size and performance of spawners and, given our control group, non-spawners. As in Gompers et al. (2005), our measure of firm size is total assets. $^{8}$ Since the asset distribution is skewed across firms, we employ the logarithm of total assets (Size). Firm performance is measured by both annual growth in sales (Sales Growth) and return on assets $(R O A)$. The latter performance variable is calculated as net income over total assets.

In addition, we use a number of control variables: we include the companies' total wage bill in our regression models. As it can be assumed that the "quality" of human capital is positively related to wage, we use this variable as a proxy for the skill composition of the spawning firms' labor force (Griliches, 1969; Devine, 1994; Arnold and Hussinger, 2005). Since the total wage bill of a firm is typically highly correlated with its size, we normalize this variable by our firm size measure. This variable is labeled Average Wage in the remainder of the paper. Furthermore, some firms decide to remain undiversified regarding their business activities and refuse exploring unrelated business opportunities. As a result, entrepreneurial employees may decide to leave the firm and start their own ventures. To control for this, we introduce a dummy variable that takes the value one for firms that are active in only one industry segment and zero otherwise (Focused).

We also account for the age of spawners and non-spawners in our regression models (Age). Since several studies have reported that especially young firms have a tendency to spawn new ventures (Gompers et al., 2005; Dobrev and Barnett, 2005; Wagner, 2004), we add a dummy variable that equals one if a spawning firm is five years old or younger and zero

\footnotetext{
${ }^{8}$ Note that employment as an alternative measure was not available to us since the datasets only provide firm size classes.
} 
otherwise (Young). Firm age is censored at 37 years in our database. The reason is that Statistics Netherlands only started its data collection process in 1967. Firms that already existed before this year are treated as if they were founded in 1967. To account for this data limitation in our empirical specifications, we create a dummy variable, which takes the value one if a firm is 37 years of age - according to the Statistics Netherlands information - and zero otherwise $($ Old $)$.

Several studies find that certain regions are more likely to prompt entrepreneurship (Venkataraman, 2004; Audretsch, 2005, 2007a, 2007b; Malecki, 1994). This result is attributed to the fact that entrepreneurship capital, which forms the capacity for entrepreneurial activity, differs within regions. Entrepreneurship capital refers to a broad spectrum of legal, institutional and social factors (Audretsch, 2007a). In order to account for the fact that different regions might have different levels of entrepreneurial capital, we add 12 region dummies corresponding to the 12 officially recognized regions that exist in the Netherlands (see Table 7 in the Appendix B). Finally, we create 34 industry dummies (see Table 8 in the Appendix B) ${ }^{9}$ and include 6 year dummies that control for business cycle effects.

\subsubsection{Descriptive Statistics: The Spawner Dataset}

Table 1 shows descriptive statistics for our sample of spawning firms and the control group of non-spawning firms. All financial variables are measured in thousands of Euros.

The descriptive statistics reveal that, on average, a spawning firm breeds roughly 2.21 ventures over the analyzed period of 6 years. This corresponds to an average of 0.39 spawned ventures per year. Comparing spawners with non-spawners shows that the former are, on average, almost four years older than the latter. Spawning firms are also much larger than non-spawning firms. This is reflected in the significantly higher average asset level. However,

\footnotetext{
${ }^{9}$ As can be seen from Table 8 in Appendix B, our industry classification is based on the 2-digit NACE industry level.
} 
non-spawning firms significantly outperform spawning firms in terms of ROA. There is no significant difference regarding the sales growth of spawning and non-spawning firms. Finally, spawning companies pay significantly higher average wages than non-spawning companies and are also less likely to be diversified.

insert Table 1 about here-

\subsection{Database 2: The Venture Dataset}

Creating a database that allows us to scrutinize if venture performance is affected by the characteristics of their spawning companies involves three steps. First, we need to link financial information to our identified set of spawned ventures. Statistics Netherlands provides financial information for a stratified sample of firms which are obliged to pay corporate taxes. About $80 \%$ of the total population of these firms is sampled by Statistics Netherlands. Since most of the spawned ventures are one-person businesses and exempted from corporate taxation, financial information is not available for them. ${ }^{10}$ As a result, our sample contains 438 ventures that are subject to corporate taxes. The 438 ventures correspond to 637 venture-year observations, which define our final venture sample.

In a second step, non-financial information is linked to these ventures. By means of this information, we are able to assess the ventures' age as well as their regional and industry affiliations. The final step is to link our subset of ventures back to their spawning companies. This reveals that the 438 ventures have been spawned by 413 firms during the period 2000$2005 .{ }^{11}$ Since our ventures stem from spawning firms in manufacturing or services, most

\footnotetext{
${ }^{10}$ Examples of such ventures that are not subject to corporate taxation are one-man consulting businesses and independent sales agents.

${ }^{11}$ The timeframe of the analysis for the spawner database is the period 1999-2004. We loose the year 2005 since we allow for a one year gap when defining our spawned ventures. For the venture database, we focus on the period 2000-2005. We lose the first year for this dataset as it is not possible to observe the previous employment situation of entrepreneurs who founded new ventures in 1999.
} 
ventures start operating in these sectors as well. Only $10 \%$ become active in non-

manufacturing or non-service industries. ${ }^{12}$

In the next subsection, the variables that are used for the empirical analysis are described.

\subsubsection{Variables: The Venture Dataset}

We examine the ventures' performance by considering two different performance measures. The first one is the ventures' returns on assets $\left(V_{-} R O A\right)$. This measure has been frequently used in studies on the performance of young and small ventures (e.g. Murphy, 1996; Robinson, 1999). Since ROA could be influenced by differences in capital structure or dividend policies across firms, we also use operating returns on assets (V_OROA) as a second performance measure. OROA is calculated as the ratio of earnings before interest and taxes (EBIT) to total assets and is a widely accepted performance measure (cf. Bennedsen, 2007 and Hvide, 2010). The fact that our sample is highly unbalanced (most of the ventures are only observed once) does not allow us to use growth measures as dependent variables since we would lose most of our observations. ${ }^{13}$

The same firm characteristics that have been used for our spawning companies are also used for the ventures. We control for the size of the ventures by taking the logarithm of total assets ( $\left.V \_S i z e\right)$. The quality of the ventures' labor force is accounted for by the average wage ( $V \_$Average Wage). We also control for the age of the ventures $\left(V \_\right.$Age $)$. Since some ventures are founded by more than one entrepreneur, we incorporate a dummy variable that takes the value one if ventures have been established by founding teams and zero otherwise (Founding

\footnotetext{
${ }^{12}$ An alternative set up would be to compare spawned ventures with a control group of ventures that have been established by entrepreneurs without any employment histories. Given our short observation period of five years, we decided to not follow this approach as we cannot determine whether the founders of the ventures within our potential control group have not been employed by a company prior to the designated time period.

${ }^{13}$ Note that our 5-years sample does not allow us to conduct a meaningful survival analysis. Only 16 ventures exit in the period 2000-2005.
} 
Team). ${ }^{14}$ Furthermore, ventures that are active in the same industry as their spawning companies might be more successful than others as they are more familiar with the industry conditions. To control for this possibility, we add a dummy variable that takes the value one if ventures and spawners are in the same industry and zero otherwise (Same Industry). Lastly, we include six industry and four region dummies for both spawned ventures and spawning companies. $^{15}$

Besides these venture characteristics, the dataset allows us to control for the attributes of the spawning firms. These spawning firm attributes have been described in section 3.1.1. The performance of spawning companies - measured by ROA and sales growth - is most important for our empirical analysis as we want to analyze if successful firms also spawn successful ventures.

\subsubsection{Descriptive Statistics: The Venture Dataset}

Our final sample consists of 637 ventures observations and their respective spawning companies. Table 2 shows descriptive statistics of this sample. ${ }^{16}$ As before, all financial variables are measured in thousands of Euros.

The results show that the average ROA $\left(V_{-} R O A\right)$ of spawned ventures is considerably lower than the average OROA $\left(V_{-} O R O A\right)$. This shows that tax and interest payments account for a large share of the ventures' returns. The average age of the ventures in the sample is 2.5 years. It can also be seen that most ventures were founded by individual entrepreneurs. Only $2 \%$ were created by founding teams. Furthermore, $26 \%$ of the ventures remain in the same industry as their parent companies.

\footnotetext{
${ }^{14}$ It is important to note that all members of the founding team must have been employed prior to the foundation of the new ventures if the variable takes the value one.

${ }^{15}$ Note that for the venture sample we use, based on the 2-digit NACE level, more aggregated regions and industries than for the spawner sample because of the smaller sample size.

${ }^{16}$ All variables starting with a "V" are venture characteristics. The same variables without the "V" account for spawning firms' characteristics.
} 
If one compares the spawning firms in the venture database with the spawning companies of the previous database containing all spawning firms in the Netherlands in our period of interest, several differences can be observed. First of all, the spawning companies in this dataset, i.e. those that spawn ventures which are subject to corporate taxation, are, on average, larger and younger. In terms of performance, the spawning firms' average ROA and average sales growth have decreased.

insert Table 2 about here

\section{Econometric Results}

In the following subsections, we present the empirical results for our three research questions. We start in section 4.1 by analyzing the effect of, inter alia, firm size and performance on the rate at which new ventures are spawned. Section 4.2 in turn is concerned with the relationship between spawning firm characteristics (the spawning firms' performance in particular) and venture performance.

\subsection{Which Firm Characteristics Influence the Spawning Rate?}

As mentioned above, we consider the annual number of newly spawned ventures as the dependent variable (Spawning Rate). Since this variable only contains positive integers and zeros, count data models are applied. Two types of count data models are estimated, namely poisson models and negative binomial models. Likelihood ratio tests for the null hypothesis of equidispersion show, however, that poisson models are always rejected. As a result, only negative binomial models are presented. ${ }^{17}$ Since firms do not spawn new ventures every year and since our sample also includes a control group of non-spawning firms, the dependent variable consists of many zero counts (74.5\%). We account for this by also estimating zero-

\footnotetext{
${ }^{17}$ The poisson estimates revealed the same results as the negative binomial models and are available from the authors upon request.
} 
inflated negative binomial models. In order to test if the zero-inflated negative binomial models outperform the standard negative binomial models, Vuong tests are performed for all model specifications. All Vuong test statistics reveal that the zero inflated models fit the data better than the standard models. ${ }^{18}$ Nevertheless, we always report both zero-inflated negative binomial models and standard negative binomial models. Clustered standard errors are used since some of the ventures are observed more often once.

The first two columns of Table 3 (Model 1 and 2) provide estimation results for the full sample of spawning firms and the control group of non-spawning firms. Both the zero inflated negative binomial model and the regular negative binomial model provide similar results. First of all, it can be seen that large companies have high spawning rates. It makes sense that large firms spawn more given that there are more people and technologies that could spark the ideas for new ventures. The positive size effect remains robust if we estimate tobit models (Model 6 and 7) in which the dependent variable is the annual number of spawned ventures normalized by total assets. ${ }^{19}$ Our first research question formulates a relationship between firm size and spawning rates. Based on the described result, it can now be concluded that large firms spawn more frequently than smaller firms, providing support for the Xerox view as suggested by Gompers et al. (2005).

The coefficient estimates of the two performance variables (Sales Growth and $R O A$ ) in Model 1 and 2 are significantly negative. By referring back to our second research question, this implies that financially unsuccessful firms spawn more ventures than successful firms (cf. Gompers et al., 2005; Eriksson and Kuhn, 2006; Hyytinen and Maliranta, 2008). One could explain this finding by arguing that the opportunity costs for staying at bad performing firms are low, leading employees to found their own entrepreneurial ventures.

\footnotetext{
${ }^{18}$ Vuong test statistics are reported at the bottom of the Table 3.

${ }^{19}$ We run tobit regressions because the dependent variable does not consist of integer values anymore and is truncated at zero. Not only does the firm size coefficient display a similar magnitude and direction as in the count data estimations, also the other main results remain comparable.
} 
Regarding the control variables, the results reveal that firms have a tendency to spawn new ventures when they are young, as indicated by the significantly negative coefficient of the Age variable. This result is consistent with studies by Dobrev and Barnett (2002) and Gompers et al. (2005). A likely explanation is that young firms are usually characterized by higher uncertainty and informational asymmetries (Gompers and Lerner, 2001; Bates, 2005). Hence, employees working for such firms might found their own ventures to forestall layoffs. Another possible explanation for our finding could be that aging firms are likely to shift their strategic focus from product innovations to process innovations. Such a strategic change could cause the character of the firms' knowledge to become embodied in physical rather than human capital, making it harder for employees to access the firms' key knowledge and found entrepreneurial ventures (Klepper and Slepper, 2005; Garvin, 1983).

Another interesting result is that firms paying high average wages also have high spawning rates (Average Wage). Since our wage variable is taken as a proxy for the skill composition of a firm's labor force it can be concluded that qualified employees are likely to generate more good ideas, which some may decide to exploit without their current employer. Finally, year dummies, industry dummies and region dummies are jointly significant throughout all two regression models, as Wald tests at the bottom of Table 3 show.

As many studies on the transition process from employment to self employment focus on firms from high tech industries (Klepper and Sleeper, 2005; Agarwal et al., 2004; Chatterij, 2009), we re-run our regression models for a subset of firms from high tech sectors (Model 3 and 4). ${ }^{20}$ This reduces the sample to 11,553 observations. The results are similar to the findings for the full sample. Young firms as well as large firms actively engage in entrepreneurial spawning. Moreover, successful firms spawn fewer ventures. The only difference to the full sample models is that just one performance variable has a significantly

\footnotetext{
${ }^{20}$ We use the official Eurostat classification to identify high tech industries (Felix, 2006).
} 
negative coefficient (ROA). Sales Growth turns insignificant. High tech firms that pay higher average wages also have higher spawning rates.

In a second robustness check we drop the control group of non-spawning firms and rerun the regressions for the subsample of spawning firms. All results remain robust. We also rerun the regressions for the subsample of 413 firms that spawn taxable ventures. It was mentioned before that these firms have spawned the 438 ventures we consider in the next part of our empirical analysis. The results are still robust: large and less successful firms have higher spawning rates. ${ }^{21}$ As a last robustness check, we estimate probit models for the likelihood of being a spawning firm. The results are in line with previous findings and can be found in Appendix A.

insert Table 3 about here-

\subsubsection{Panel Models}

The cross sectional regression results have shown that large firms as well as firms with unfavorable sales growth and ROA have higher spawning rates than successful firms. Since cross sectional results do not take into account that unobserved firm heterogeneity (due to differences in management skills, entrepreneurial climate within the firm etc.) could drive spawning rates as well, we also estimate panel models with firm fixed effects. More specifically, we estimate fixed effects poisson models as introduced by Hausman et al. (1984). Gourieroux et al. (1984) have shown that the poisson estimator is consistent for panel data even if the dependent variable does not truly follow a poisson-distribution as long as the mean specification is correct. In addition, previous research has shown that a significant portion of the overdispersion is accounted for if one allows for random or fixed disturbances (Hausman et al., 1984). The fixed effects in our poisson model then control for some of the

\footnotetext{
${ }^{21}$ The regression results are available from the authors on request.
} 
overdispersion in the data. If fully robust standard errors are calculated, the fixed effects poisson models even provide protection against any residual overdispersion. Hence, we prefer poisson estimators over negative binomial models for our panel data models. Compared to the negative binomial panel models, this ensures that no assumption regarding the functional form of the variance term is necessary since one would have to cope with inconsistent estimates if this assumption fails.

Model 7 in Table 4 reports the estimates of the fixed effects quasi maximum likelihood poisson model for our full sample. As before, large firms have high rates of entrepreneurial spawning, which is unsurprising given that more people work there. To this end, we confirm this finding by estimating panel tobit models in which the dependent variable is normalized by total assets. The results in Model 9 reveal that large firms still have high spawning rates. Although the count data results show that spawning is unrelated to sales growth, a highly significant and negative effect is found for ROA. Hence, it can be concluded that employees do not leave firms that are well performing, but instead when firm performance (in terms of ROA) is low. Most employees decide to create their own ventures and pursue entrepreneurial opportunities outside the firm when the opportunity costs for remaining employed are diminished (also see Gompers et al., 2005; Hyytinen and Maliranta, 2008; Erikkson and Kuhn, 2006). The final result of Model 7 shows that firms paying high average wages also have higher spawning levels.

Running the fixed effects quasi-maximum likelihood poisson regressions (Model 8) as well as the tobit models (Model 10) for a subset of high tech firms, reveals the same results. The signs and magnitudes of the variables are quite similar and also the significance levels have not changed.

In summary, it can be said that controlling for unobserved firm heterogeneity does not change the answers to our two research questions regarding the effect of firm size and performance on spawning rates. 


\subsection{Providing a Link between Venture Performance and Spawner Characteristics}

The entrepreneurship literature remains quiet when it comes to scrutinizing if the performance of spawned ventures is affected by their origin. To shed some light on this question, we run OLS regressions with the performance of the spawned ventures as the dependent variable (in terms of $V_{-} R O A$ and $V_{-} O R O A$ ) and venture and spawner characteristics as independent variables. Models 11 and 13 in Table 5 only regress the dependent variables on venture characteristics. In Model 12 and 14, we add the characteristics of the ventures' former employers. ${ }^{22}$

The results of Model 12 reveal that venture size has a positive impact on performance. Surprisingly, all other venture characteristics are insignificant. Regarding the spawning firms' characteristics, it can be seen that the better the performance of the spawning companies (in terms of $R O A$ ), the better the performance of the ventures (cf. Franco and Filson, 2006, and the references within Klepper, 2009). This result supports our third research question claiming that the financial success of the parent firms influences the financial success of the spawned ventures. One interpretation of this finding could be that venture founders who worked at such firms were able to access and exploit more valuable knowledge, possibly resulting in increased venture performance. An alternative explanation is provided by Klepper (2009) and Chatterij (2009). They argue that better firms have better employees who are more likely to start new ventures, which also perform better. Chatterij (2009) calls this the "good people work for good firms" explanation. We try to control for this objection by including average wage as a proxy for the skill level of the spawning firms' employees in our regressions.

\footnotetext{
${ }^{22}$ Note that we lose some observations for these regressions (Model 12 - Model 14) as we add the sales growth of the spawning firms, which costs us one year by definition of the measure. The regression results for Model 11 - Model 13 are robust if the reduced sample of Model 12 - Model 14 is used.
} 
Running the same regressions for our second performance variable ( $\left.V \_O R O A\right)$ yields similar results. Size is the only venture characteristic that has a significant and positive effect on performance. Most importantly, however, it can still be shown that ventures of successful spawning firms (in terms of ROA) turn out to be successful as well, lending support to our third research question. ${ }^{23}$

Given that successful firms spawn few (as was discussed in the previous subsection) but profitable ventures it can be concluded that it employees of such firms are more reluctant to quit and create new ventures than employees of struggling companies. Working for a successful firm increases the opportunity costs of leaving so that employees only opt for the pursuit of entrepreneurial opportunities if the expected returns are high enough. For this reason, Erikkson and Kuhn (2006) describe ventures that have been spawned by profitable firms to be pulled by the market. This argument is in line with the superior performance of ventures spawned by successful firms as was just described.

\section{Conclusion}

The employment history of entrepreneurs has attracted the interest of academic scholars in recent years. Several studies argue that entrepreneurs got inspired by business ideas they came across at their previous employers (Klepper, 2001; Agarwal et al., 2004; Klepper and Sleeper, 2005; Cassiman and Ueda, 2006; Hyytinen and Maliranta, 2008). This process, by which former employees become entrepreneurs and found new ventures, is known as entrepreneurial spawning. Previous literature has already identified firm size and performance as important characteristics influencing the rate at which new ventures are spawned. The question if these spawning firm characteristics can also influence the financial success of new

\footnotetext{
${ }^{23}$ The result remains robust when we use OROA instead of ROA as a measure for the financial success of the spawning firm. Results are available from the authors upon request.
} 
ventures, however, remains unanswered by existing studies. This paper provides a first empirical investigation of this research gap. In particular, we are interested in the question if successful firms spawn financially successful ventures.

Our analysis is based on the official employee-employer data sets of Statistics Netherlands. These data sets allow us to identify all spawning firms along with the newly created ventures. Based on this information we investigate three related questions. First, we follow previous studies and determine the effect of firm size and performance on the rate at which new ventures are spawned. As an answer to our first two research questions, the results show that large firms as well as firms lacking a good financial performance are the most active spawners. The former finding is in accordance with an earlier study by Gompers et al. (2005). Employees seem to create new ventures because they are frustrated that the large firms for which they work are unable or unwilling to fund their entrepreneurial ideas. Our second finding that there is a negative relationship between firm performance and spawning rate is a consistent finding throughout most studies (cf. Erikkson and Kuhn, 2006; Hyytinen and Maliranta, 2008; Wagner, 2004). Employees found their own ventures if the performance of their employers drop and the rents from staying at the firm are reduced (cf. Erikkson and Kuhn, 2006; Hyytinen and Maliranta, 2008; Wagner, 2004). This suggests that most new ventures are rather "pushed" by crises at the spawning firms (e.g. bad performances) and not "pulled" by the market or the wish to follow a business idea independently (Erikkson and Kuhn, 2006).

The second part of our analysis answers the research question if the financial performance of entrepreneurial ventures is affected by the characteristics of their spawning companies. Specifically, we are interested in examining the relationship between the ventures' performance and the spawning firms' performance. We find, in accordance with our research question, that firms exhibiting a good performance also spawn successful ventures. A possible explanation for this finding is that well performing companies possess valuable and distinct 
knowledge, which their employees are able to exploit for founding and running successful ventures (Klepper, 2009; Agarwal et al., 2004; Franco and Filson, 2006; Erikkson and Kuhn, 2006). In fact, founders of pulled ventures not only learnt important knowledge about technologies (Klepper and Sleeper, 2005; Agarwal et al., 2004), markets (Jovanovic, 1982; Agarwal et al., 2004) and organizational processes (Buenstorf, 2009) from their previous employers, but also established important contacts with suppliers and customers, which they can now take advantage of (Helfat and Lieberman, 2002).

Finally, our analysis suggests that well performing firms spawn few but successful ventures. It seems that employees of such firms are more reluctant to quit and create new ventures than employees of struggling companies. In the former case, the opportunity costs of leaving are higher so that employees are only deciding to pursue entrepreneurial opportunities if the expected returns are high enough. This result is consistent with the superior performance of ventures spawned by successful firms as depicted before.

Our findings have important implications. In particular, they suggest that large firms, which have high spawning rates, might want to encourage the internal pursuit of entrepreneurial ideas if employees should be persuaded to stay. One way to do so would be the creation of corporate ventures $(\mathrm{CVs})$ in which employees' entrepreneurial ideas are implemented. Corporate ventures are autonomous or semi-autonomous firms that reside within the organizational domains of their founding companies. An advantage of corporate ventures is that they can operate rather independently but still rely on the resources of their corporate sponsors (Hill and Rothaermel, 2003; Sharma and Chrisman, 1999). Recent research has shown that these specific characteristics make corporate ventures do well at generating radically new innovations (Czarnitzki et al., 2010). Cassiman and Ueda (2006) argue, however, that firms have a limited capacity for corporate venturing. This means that not all entrepreneurial ideas can be capitalized on. Firms have to consider the returns from an 
employee's innovation against both cannibalization effects and the option value of waiting for better projects in the future. Hence, corporate venturing is only feasible to a certain extent.

Our study is not free of limitations. First of all, we are not able to measure directly if venture founders have learnt something from their previous employers. We can only conclude indirectly that employees of better performing firms must have learnt valuable knowledge that facilitates the creation of successful ventures. Previous studies could state more specifically if employees have inherited knowledge from their previous employers (Agarwal et al., 2004, and Franco and Filson, 2006). In fact, both studies were able to distinguish between different knowledge types. The reason is that the authors can make use of specific knowledge measures that are only applicable to the disk drive industry. Agarwal et al. (2004), for instance, use these industry specific knowledge measures to approximate technical knowledge and marketing knowledge. Also Chatterij (2009) accounts for technical knowledge in his empirical analysis on the medical device industry and confirms the importance of marketing knowledge by conducting interviews with venture founders. Such detailed information, however, come at a cost as the data samples of these studies are restricted to certain industry. While lacking some of the detailed information used in prior research, our study has the advantage that it is based on samples that cover the whole Dutch manufacturing and service industries.

Second, our analysis relies on an unbalanced sample of spawned ventures so that we cannot use growth measures to further test the robustness of our results. Information on the exit dates of the ventures is also missing since our panel is too short to observe many firm exits. Accordingly, a survival analysis cannot be performed either. Third, we lack information on the innovativeness of the last employers and the spawned ventures. Since we have only access to anonymized data sets at Statistics Netherlands and cannot observe firm names, we are not able to link publicly available patent records to our ventures and spawning firms. 
A possible venue for future research would be to assess if the performance of the spawning companies worsens after their entrepreneurial employees leave to found new ventures. In this context, it would be interesting to obtain more information on the employment history of the spawned employees. What kind of positions did they hold at their previous employers? Is venture performance dependent on how long they worked for the spawning companies?

\section{References}

Agarwal, R., Echambadi, R., Franco, A. M., \& Sarkar, M. (2004). Knowledge Transfer through Inheritance: Spin-out Generation, Development, and Survival. The Academy of Management Journal, 47(4), 501-522.

Arnold, J., \& Hussinger, K. (2005). Export Behavior and Firm Productivity in German Manufacturing: A firm-level analysis. Review of World Economics,, 141(2), 219-243.

Audretsch, D. B. (2007a). Entrepreneurship capital and economic growth. Oxford Review of Economic Policy, 23(1), 63-78.

Audretsch, D. B. (2005). Entrepreneurship capital and regional growth. The Annals of Regional Science, 39(3), 457-469.

Audretsch, D. B. (2007b). The localisation of entrepreneurship capital: Evidence from Germany. Papers in Regional Science, 86(3), 351-365.

Bates, T. (2005). Analysis of young, small firms that have closed: delineating successful from unsuccessful closures. Journal of Business Venturing, 20(3), 343-358.

Bennedsen, M., Nielsen, K. M., Pérez-González, F., \& Wolfenzon, D. (2007). Inside the Family Firm: the Role of Families in Succession Decisions and Performance. Quarterly Journal of Economics, 122, 647-691.

Berger, P. G., \& Ofek, E. (1995). Diversification's effect on firm value. Journal of Financial Economics, 37(1), 39-65. 
Bhidé, A. (1994). How entrepreneurs craft strategies that work. Harvard Business Review, 72(2), 150-161.

Boschma, R., \& Wenting, R. (2007). The spatial evolution of the British automobile industry: Does location matter? Industrial and Corporate Change, 16(2), 213-238.

Buenstorf, G. (2009). Opportunity spin-offs and necessity spin offs. International Journal of Entrepreneurial Venturing, 1(1), 22-40.

Cassiman, B., \& Ueda, M. (2006). Optimal Project Rejection and New Firm Start-ups. Management Science, 52(2), 262-275.

Chandler, G. (1996). Business Similarity as a Moderator of the Relationship between preownership Experience and Venture Performance. Entrepreneurship, Theory and Practice, 20, 51-65.

Chatterji, A. (2009). Spawned with a silver spoon? Entrepreneurial performance and innovation in the medical device industry. Strategic Management Journal, 30(2), $185-$ 206.

Cooper, A. C. (1985). The role of incubator organizations in the founding of growth-oriented firms. Journal of Business Venturing, 1(1), 75-86.

Czarnitzki, D., Dick, J., \& Hussinger, K. (2010). The Contribution of Corporate Ventures to Radical Innovation. ZEW Discussion Paper No. 10-060.

Devine, T. J. (1994). Changes in Wage-and-Salary Returns to Skill and the Recent Rise in Female Self-Employment. The American Economic Review, 84(2), 108-113.

Dobrev, S., \& Barnett, W. (2005). Organizational roles and transition to entrepreneurship. Academy of Management Journal, 48(3), 433-449.

Elfenbein, D. W., Hamilton, B. H., \& Zenger, T. R. (2010). The Small Firm Effect and the Entrepreneurial Spawning of Scientists and Engineers. Management Science, 1-23.

Eriksson, T., \& Moritz Kuhn, J. (2006). Firm spin-offs in Denmark 1981-2000 -- patterns of entry and exit. International Journal of Industrial Organization, 24(5), 1021-1040. 
Felix, B. (2006). High tech industries and knowledge based services: Eurostat.

Franco, A. M., \& Filson, D. (2006). Spin-outs: knowledge diffusion through employee mobility. The RAND Journal of Economics, 37(4), 841-860.

Garvin, D. (1983). Spin-offs and the new firm formation process. California Management Review, $X X V(2), 3-20$.

Gompers, P., \& Lerner, J. (2001). The Venture Capital Revolution. The Journal of Economic Perspectives, 15(2), 145-168.

Gompers, P., Lerner, J., \& Scharfstein, D. (2005). Entrepreneurial Spawning: Public Corporations and the Genesis of New Ventures, 1986 to 1999. The Journal of Finance, 60(2), 577-614.

Gourieroux, C., Monfort, A., \& Trognon, A. (1984). Pseudo Maximum Likelihood Methods: Theory. Econometrica, 52(3), 681-700.

Griliches, Z. (1969). Capital-Skill Complementarity. The Review of Economics and Statistics, $51(4), 465-468$.

Hausman, J., Hall, B. H., \& Griliches, Z. (1984). Econometric Models for Count Data with an Application to the Patents-R \& D Relationship. Econometrica, 52(4), 909-938.

Helfat, C., \& Lieberman, M. (2002). The birth of capabilities: market entry and the importance of pre-history. Industrial and Corporate Change, 11(4), 725-760.

Hellmann, T. (2007). When Do Employees Become Entrepreneurs? Management Science, 53(6), 919-933.

Henderson, R. (1993). Underinvestment and Incompetence as Responses to Radical Innovation: Evidence from the Photolithographic Alignment Equipment Industry. The RAND Journal of Economics, 24(2), 248-270.

Hill, C., \& Rothaermel, F. (2003). The performance of incumbent firms in the face of radical technological innovation. The Academy of Management Review, 28(2), 257-274.

Hvide, H. (2010). The Quality of Entrepreneurs. The Economic Journal, 119, 1010-1035. 
Hyytinen, A., \& Maliranta, M. (2008). When Do Employees Leave Their Job for Entrepreneurship? The Scandinavian Journal of Economics, 110(1), 1-21.

Jovanovic, B., (1982). Selection and the evolution of industry. Econometrica, 50, 649-670.

Klepper, S. (2001). Employee Startups in High-Tech Industries. Industrial and Corporate Change, 10(3), 639-674.

Klepper, S. (2007). Disagreements, Spinoffs, and the Evolution of Detroit as the Capital of the U.S. Automobile Industry. Management Science, 53(4), 616-631.

Klepper, S., \& Sleeper, S. (2005). Entry by Spinoffs. Management Science, 51(8), 1291-1306.

Klepper, S., \& Thompson, P. (2010). Disagreements and intra-industry spinoffs. International Journal of Industrial Organization, 28, 526-538.

Lazear, E. P. (2004). Balanced Skills and Entrepreneurship. The American Economic Review, 94(2), 208-211.

Lazear, E. P. (2005). Entrepreneurship. Journal of Labor Economics, 23(4), 649-680.

Malecki, E. (1994). Entrepreneurship in Regional and Local Development. International Regional Science Review, 16(1), 119-153.

Miller, M., \& Kroll, L. (2010). The World's Billionaires. Forbes Magazine.

Murphy, G. B., Trailer, J. W., \& Hill, R. C. (1996). Measuring performance in entrepreneurship research. Journal of Business Research, 36(1), 15-23.

Parker, S. (2006). A selection-based theory of the transition from employment to entrepreneurship: The role of employer size. IZA Discussion Paper, NO.2071.

Robinson, K. C. (1999). An examination of the influence of industry structure on eight alternative measures of new venture performance for high potential independent new ventures. Journal of Business Venturing, 14(2), 165-187.

Sharma, P., \& Chrisman, J. (1999). Toward a reconciliation of the definitional issues in the field of corporate entrepreneurship. Entrepreneurship, Theory and Practice, 23(3), 1127. 
Sørensen, J. (2007). Bureaucracy and entrepreneurship: Workplace effects on entrepreneurial entry. Administrative Science Quarterly, 52, 387-412.

Stinchcombe, A. L. (1965). Organizations and Social Structure. In J. G. March (Ed.), Handbook of Organizations (pp. 142-193). Chicago, IL: Rand McNally.

Sull, D. (1999). Why good companies go bad. Harvard Business Review, 42-52.

Tripsas, M., \& Gavetti, G. (2000). Capabilities, cognition, and inertia: evidence from digital imaging. Strategic Management Journal, 21(10-11), 1147-1161.

Tushman, M. L., \& Anderson, P. (1986). Technological Discontinuities and Organizational Environments. Administrative Science Quarterly, 31(3), 439-465.

Vandenheuvel, A., \& Wooden, M. (1997). Self-Employed Contractors and Job Satisfaction. Journal of Small Business Management, 35(3), 11-20.

Venkataraman, S. (2004). Regional transformation through technological entrepreneurship. Journal of Business Venturing, 19(1), 153-167.

Wagner, J. (1994). The Post-Entry Performance of New Small Firms in German Manufacturing Industries. The Journal of Industrial Economics, 42(2), 141-154.

Wagner, J. (2004). Are Young and Small Firms Hothouses for Nascent Entrepreneurs? Evidence from German Micro Data. IZA Discussion Paper, No.989. 


\section{Appendix A}

Whereas section 4.1 shed light on the effect of, inter alia, firm size and performance on a firm's rate of entrepreneurial spawning, we now analyze the attributes that determine whether firms spawn at all. A dummy variable, equaling one if a firm spawns at least one venture and zero otherwise (Spawner), was created to address this question.

insert Table 6 about here-

Overall, the probit regressions in Table 6 largely support the key results from section 4.1 in the sense that those firms displaying a high spawning rate are also the ones that are most likely to spawn at least one entrepreneurial venture. Large firms, young firms and firms with an inferior performance have both a high spawning rate and a high likelihood of spawning at least one new venture. The results remain robust if one only considers the subsample of high tech firms (Model 16). The main difference to the results from section 4.1 lies in the fact that focused firms (Focused), extremely young firms (Young) and old companies $(O l d)$ are more likely to spawn new ventures, although these characteristics had no impact on spawning rates.

\section{Appendix B}

-insert Table 7 about here-

-insert Table 8 about here- 


\section{Tables}

Table 1: Descriptive Statistics: Spawner Dataset

\begin{tabular}{|c|c|c|c|c|c|c|}
\hline \multirow[b]{2}{*}{ Variables } & \multicolumn{2}{|c|}{$\begin{array}{c}\text { Spawner } \\
(\mathrm{N}=52597)\end{array}$} & \multicolumn{2}{|c|}{$\begin{array}{c}\text { Non-Spawner } \\
(\mathrm{N}=69675) \\
\end{array}$} & \multirow{2}{*}{$\begin{array}{c}\text { Mean } \\
\text { Difference }\end{array}$} & \multirow[b]{2}{*}{$\mathrm{t}$} \\
\hline & Mean & SD & Mean & SD & & \\
\hline Total Spawning & 2.21 & 11.85 & / & / & l & / \\
\hline Spawning Rate & 0.39 & 2.26 & / & l & l & / \\
\hline Size & 7.51 & 1.91 & 6.29 & 1.42 & 1.22 & $130.00 * * *$ \\
\hline $\mathrm{ROA}$ & 0.04 & 0.19 & 0.05 & 0.22 & -0.01 & $-3.81 * * *$ \\
\hline Sales Growth & 0.02 & 0.35 & 0.02 & 0.39 & 0.00 & -0.89 \\
\hline Age & 18.53 & 11.63 & 14.75 & 11.25 & 3.78 & $57.26 * * *$ \\
\hline Young & 0.16 & 0.002 & 0.27 & 0.002 & -0.11 & $-46.45 * * *$ \\
\hline Old & 0.03 & 0.18 & 0.02 & 0.14 & 0.01 & $16.05 * * *$ \\
\hline Average Wage & 0.49 & 0.41 & 0.41 & 0.37 & 0.08 & $38.19 * * *$ \\
\hline Focused & 0.36 & 0.48 & 0.21 & 0.41 & 0.15 & $57.77 * * *$ \\
\hline
\end{tabular}

Note: Industry dummies, year dummies and region dummies are omitted.

Table 2: Descriptive Statistics: Venture Dataset

\begin{tabular}{lcccc}
\hline & \multicolumn{4}{c}{$\mathrm{N}=637$} \\
\hline V_ROA & Mean & SD & Min & Max \\
\hline V_OROA & 0.003 & 0.22 & -1 & 0.58 \\
V_Size & 0.04 & 0.20 & -0.93 & 0.62 \\
V_Age & 5.53 & 1.42 & 0.69 & 9.49 \\
V_Average Wage & 2.58 & 1.74 & 0 & 5 \\
V_Founding Team & 0.32 & 0.36 & 0 & 1.97 \\
Size & 0.02 & 0.14 & 0 & 1 \\
ROA & 8.79 & 3.23 & 1.39 & 17.43 \\
Sales Growth & 0.01 & 0.17 & -0.29 & 1 \\
Age & -0.016 & 0.21 & -0.56 & 0.94 \\
Young & 15.11 & 10.57 & 1 & 37 \\
Old & 0.23 & 0.42 & 0 & 1 \\
Average Wage & 0.022 & 0.15 & 0 & 1 \\
Focused & 0.41 & 0.40 & 0 & 1.97 \\
Related & 0.94 & 0.23 & 0 & 1 \\
\hline Ne: & 0.26 & 0.44 & 0 & 1 \\
\hline
\end{tabular}

Note: Industry dummies, year dummies and region dummies are omitted for both ventures and spawners

${ }^{a}$ Since we lose one year in creating the sales growth variable, we only end up with 426 observations. 
Table 3: Count Data Results and Tobit Results on the Annual Spawning Rate for the Full Sample and the High Tech Subsample Dependent Variable:

Dependent Variable:

Spawning Rate

Spawning Rate/Total Assets

\begin{tabular}{|c|c|c|c|c|c|c|}
\hline & $\begin{array}{l}\text { ZI Negative } \\
\text { Binomial }^{\mathrm{a}}\end{array}$ & $\begin{array}{l}\text { Negative } \\
\text { Binomial }\end{array}$ & $\begin{array}{l}\text { ZI Negative } \\
\text { Binomial }^{\mathrm{a}} \\
\end{array}$ & $\begin{array}{l}\text { Negative } \\
\text { Binomial }\end{array}$ & $\begin{array}{l}\text { Tobit } \\
\text { Model }\end{array}$ & $\begin{array}{l}\text { Tobit } \\
\text { Model }\end{array}$ \\
\hline Sample & \multicolumn{2}{|c|}{$\begin{array}{l}\text { Full } \\
\text { Sample }\end{array}$} & \multicolumn{2}{|c|}{$\begin{array}{l}\text { High Tech } \\
\text { Sample }\end{array}$} & $\begin{array}{c}\text { Full } \\
\text { Sample }\end{array}$ & $\begin{array}{c}\text { High Tech } \\
\text { Sample }\end{array}$ \\
\hline Variables & Model 1 & Model 2 & Model 3 & Model 4 & Model 5 & Model 6 \\
\hline Size & $\begin{array}{c}0.52 * * * \\
(0.01)\end{array}$ & $\begin{array}{l}0.52 * * * \\
(0.01)\end{array}$ & $\begin{array}{c}0.55 * * * \\
(0.02)\end{array}$ & $\begin{array}{l}0.55 * * * \\
(0.03)\end{array}$ & $\begin{array}{c}0.02 * * * \\
(0.06)\end{array}$ & $\begin{array}{l}0.01 * * \\
(0.006)\end{array}$ \\
\hline $\mathrm{ROA}$ & $\begin{array}{c}-0.43 * * * \\
(0.07)\end{array}$ & $\begin{array}{c}-0.43 * * * \\
(0.06)\end{array}$ & $\begin{array}{c}-0.46 * * * \\
(0.12)\end{array}$ & $\begin{array}{c}-0.54 * * * \\
(0.12)\end{array}$ & $\begin{array}{c}-0.03 * * * \\
(0.07)\end{array}$ & $\begin{array}{c}-0.02 * * \\
(0.09)\end{array}$ \\
\hline Sales Growth & $\begin{array}{c}-0.16 * * * \\
(0.04)\end{array}$ & $\begin{array}{c}-0.14 * * * \\
(0.03)\end{array}$ & $\begin{array}{l}-0.02 \\
(0.08)\end{array}$ & $\begin{array}{l}-0.01 \\
(0.08)\end{array}$ & $\begin{array}{c}-0.06 * * * \\
(0.02)\end{array}$ & $\begin{array}{c}0.001 \\
(0.003)\end{array}$ \\
\hline Age & $\begin{array}{c}-0.01 * * * \\
(0.001)\end{array}$ & $\begin{array}{c}-0.01 * * * \\
(0.01)\end{array}$ & $\begin{array}{l}-0.01 * * \\
(0.004)\end{array}$ & $\begin{array}{l}-0.01 * * \\
(0.004)\end{array}$ & $\begin{array}{l}-0.001 * * \\
(0.0001)\end{array}$ & $\begin{array}{l}-0.001 * \\
(0.0001)\end{array}$ \\
\hline Young & $\begin{array}{l}-0.05 \\
(0.04)\end{array}$ & $\begin{array}{l}-0.03 \\
(0.04)\end{array}$ & $\begin{array}{l}-0.05 \\
(0.08)\end{array}$ & $\begin{array}{l}-0.08 \\
(0.09)\end{array}$ & $\begin{array}{l}0.000 \\
(0.02)\end{array}$ & $\begin{array}{c}-0.004 \\
(0.003)\end{array}$ \\
\hline Old & $\begin{array}{c}0.16 \\
(0.10)\end{array}$ & $\begin{array}{l}0.19 * * \\
(0.09)\end{array}$ & $\begin{array}{l}-0.06 \\
(0.38)\end{array}$ & $\begin{array}{l}-0.04 \\
(0.37)\end{array}$ & $\begin{array}{c}0.07 \\
(0.05)\end{array}$ & $\begin{array}{l}-0.002 \\
(0.01)\end{array}$ \\
\hline Average Wage & $\begin{array}{c}0.91 * * * \\
(0.06)\end{array}$ & $\begin{array}{c}1.13 * * * \\
(0.04)\end{array}$ & $\begin{array}{c}1.11 * * * \\
(0.07)\end{array}$ & $\begin{array}{c}1.12 * * * \\
(0.07)\end{array}$ & $\begin{array}{c}0.06 * * * \\
(0.02)\end{array}$ & $\begin{array}{c}0.03 * * \\
(0.01)\end{array}$ \\
\hline Focused & $\begin{array}{l}-0.02 \\
(0.03)\end{array}$ & $\begin{array}{c}0.01 \\
(0.03)\end{array}$ & $\begin{array}{l}-0.01 \\
(0.07)\end{array}$ & $\begin{array}{r}-0.003 \\
(0.08)\end{array}$ & $\begin{array}{c}0.006 * * \\
(0.02)\end{array}$ & $\begin{array}{c}0.003 \\
(0.003)\end{array}$ \\
\hline \multirow[t]{6}{*}{ Intercept } & $\begin{array}{c}-8.04 * * * \\
(0.13)\end{array}$ & $\begin{array}{c}-8.39 * * * \\
(0.09)\end{array}$ & $\begin{array}{c}-8.69 * * * \\
(0.32)\end{array}$ & $\begin{array}{c}-8.64 * * * \\
(0.34)\end{array}$ & $\begin{array}{c}-0.44 * * * \\
(0.13)\end{array}$ & $\begin{array}{c}-0.27 * * \\
(0.11)\end{array}$ \\
\hline & \multicolumn{6}{|c|}{ Joint Significance of Year Dummies, $\chi^{2}$ (4) } \\
\hline & \multicolumn{5}{|c|}{ Joint Significance of Industry Dummies, $\chi 2$ (33) } & 1.78 \\
\hline & $388.67 * * *$ & $434.55 * * *$ & $18.32 * * \mathrm{~b}$ & $17.61 * * b$ & 0.6 & $0.69^{b}$ \\
\hline & \multicolumn{6}{|c|}{ Joint Significance of Region Dummies, $\chi^{2}$ (11) } \\
\hline & $123.32 * * *$ & $145.83 * * *$ & $19.59 *$ & $19.16^{*}$ & 1.13 & 0.44 \\
\hline Log-Likelihood & -41250.03 & -41472.61 & -3819.47 & -3828.25 & -8387.29 & -127.91 \\
\hline Vuong Test Statistic & $10.39 * * *$ & / & $3.15 * * *$ & 1 & / & I \\
\hline Observations & 122272 & 122272 & 11553 & 11553 & 122272 & 11553 \\
\hline
\end{tabular}

Notes: Clustered standard errors in parentheses; *** $(* *, *)$ indicate a significance level of $1 \%(5 \%, 10 \%)$.

${ }^{\mathrm{a}}$ The inflation equation includes the same variables as the logit equation (Coefficient estimates are not reported).

${ }^{\mathrm{b}}$ Test of Joint Significance of Industry Dummies, $\chi 2$ (8) 
Table 4: Panel Models on the Annual Spawning Rate for the Full Sample and the High Tech Subsample

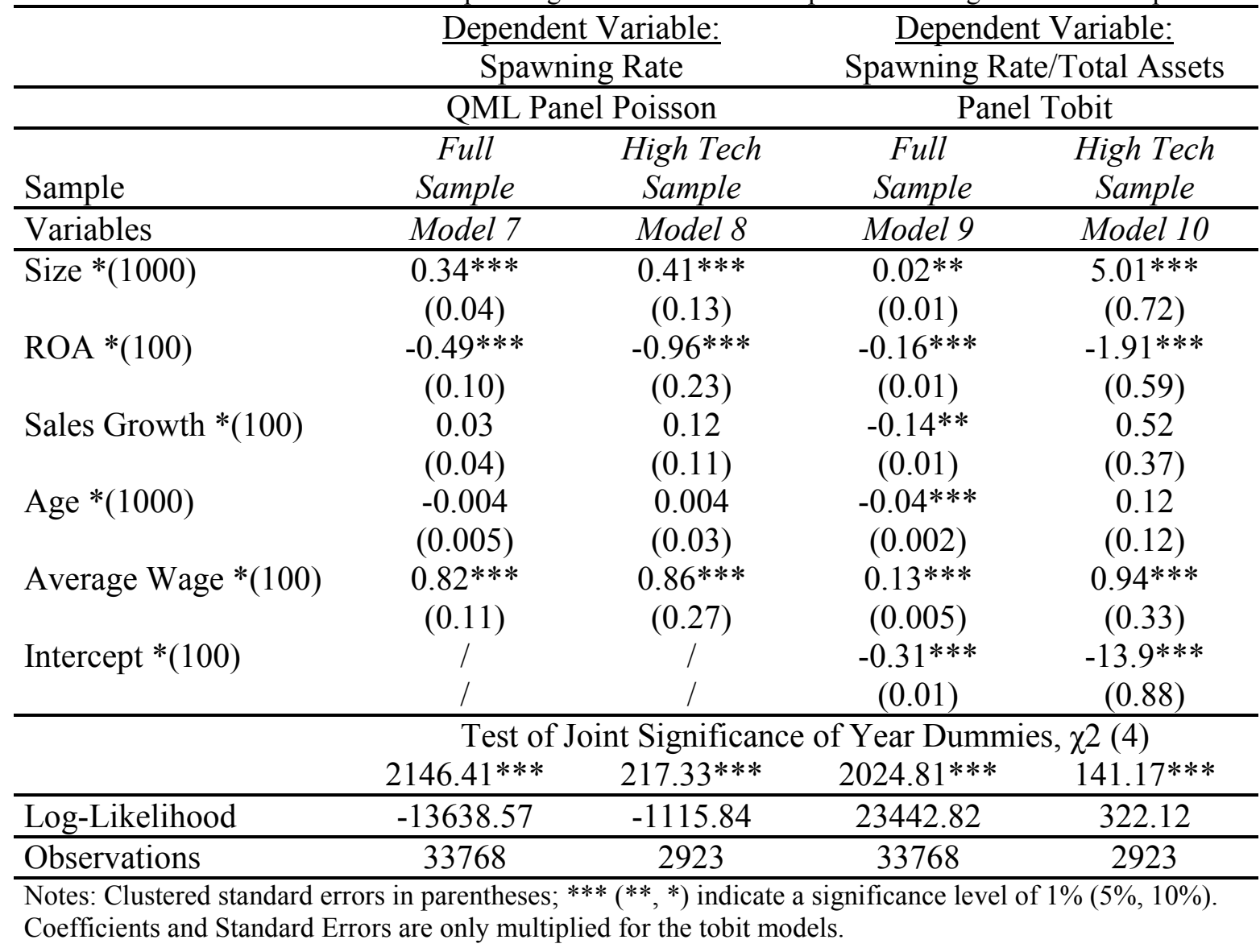


Table 5: OLS Results on the Ventures' Performance for the Full Sample

\begin{tabular}{|c|c|c|c|c|}
\hline & \multicolumn{2}{|c|}{ Dependent Variable: V_ROA } & \multicolumn{2}{|c|}{ Dependent Variable: V_OROA } \\
\hline Variables & Model 11 & Model 12 & Model 13 & Model 14 \\
\hline \multirow[t]{2}{*}{ V_Size } & $0.02 * *$ & $0.03 * *$ & $0.02 * *$ & $0.03 * * *$ \\
\hline & $(0.01)$ & $(0.01)$ & $(0.01)$ & $(0.01)$ \\
\hline \multirow[t]{2}{*}{ V_Age $(* 100)$} & 0.02 & -0.42 & -0.31 & -0.83 \\
\hline & $(0.71)$ & $(1.33)$ & $(0.72)$ & $(1.21)$ \\
\hline \multirow[t]{2}{*}{$\mathrm{V}_{-}$Average Wage $(* 100)^{\mathrm{a}}$} & -0.04 & 0.01 & 0.02 & 0.04 \\
\hline & $(0.03)$ & $(0.04)$ & $(3.12)$ & $(0.04)$ \\
\hline \multirow[t]{2}{*}{ V_Founding Team } & $-0.11 *$ & -0.07 & -0.07 & -0.07 \\
\hline & $(0.05)$ & $(0.08)$ & $(0.05)$ & $(0.07)$ \\
\hline \multirow[t]{2}{*}{ Size $(* 100)$} & I & 0.07 & l & 0.04 \\
\hline & / & $(0.42)$ & / & $(0.43)$ \\
\hline \multirow[t]{2}{*}{ ROA } & / & $0.19 * *$ & / & $0.16^{* *}$ \\
\hline & / & $(0.09)$ & / & $(0.08)$ \\
\hline \multirow[t]{2}{*}{ Sales Growth } & / & -0.04 & / & -0.06 \\
\hline & / & $(0.06)$ & / & $(0.05)$ \\
\hline \multirow[t]{2}{*}{ Age $(* 100)$} & / & 0.03 & / & 0.005 \\
\hline & / & $(0.21)$ & / & $(0.11)$ \\
\hline \multirow[t]{2}{*}{ Young } & / & 0.02 & / & 0.02 \\
\hline & / & $(0.04)$ & / & $(0.03)$ \\
\hline \multirow[t]{2}{*}{ Old } & / & -0.04 & / & 0.04 \\
\hline & / & $(0.12)$ & / & $(0.07)$ \\
\hline \multirow[t]{2}{*}{ Average Wage $(* 10)$} & / & -0.02 & l & 0.02 \\
\hline & / & $(0.45)$ & / & $(0.39)$ \\
\hline \multirow[t]{2}{*}{ Focused } & / & 0.02 & / & 0.02 \\
\hline & / & $(0.06)$ & / & $(0.06)$ \\
\hline \multirow[t]{2}{*}{ Same Industry } & / & 0.03 & / & 0.03 \\
\hline & / & $(0.03)$ & / & $(0.03)$ \\
\hline \multirow[t]{2}{*}{ Intercept } & -0.11 & -0.16 & -0.06 & -0.12 \\
\hline & $(0.07)$ & $(0.12)$ & $(0.06)$ & $(0.11)$ \\
\hline $\mathrm{R}^{2}$ & 0.04 & 0.11 & 0.03 & 0.12 \\
\hline Test of Joint Significance of the Venture FoundationYear Dummies, $\chi 2$ (5) & 1.23 & 1.45 & 1.28 & 1.27 \\
\hline Test of Joint Significance of the Venture Industry Dummies, $\chi 2$ (5) & 0.51 & 0.77 & 0.51 & 0.97 \\
\hline Test of Joint Significance of the Venture Region Dummies, $\chi 2$ (3) & 0.67 & 0.26 & 0.49 & 0.11 \\
\hline Test of Joint Significance of the Year Dummies, $\chi^{2}(5)$ & / & 1.12 & / & 1.05 \\
\hline Test of Joint Significance of the Spawner Industry Dummies, $\chi 2$ (5) & / & 1.83 & / & 1.81 \\
\hline Test of Joint Significance of the Spawner Region Dummies, $\chi 2$ (3) & / & 1.01 & / & 1.05 \\
\hline Observations & 637 & 426 & 637 & 426 \\
\hline
\end{tabular}

Notes: Clustered standard errors in parentheses; $* * *(* *, *)$ indicate a significance level of $1 \%(5 \%, 10 \%)$

${ }^{\mathrm{a}}$ Only the coefficient and standard error of $V_{-}$Average Wage in Model 12 have been multiplied by 100. 
Table 6: Probit Regression Results on being a Spawner for the Full Sample and the High Tech Subsample

Dependent Variable: Spawner (1/0)

\begin{tabular}{lcc}
\hline Variables & Model 15 & Model 16 \\
\hline Size & $0.33^{* *}$ & $0.38^{* * *}$ \\
& $(0.005)$ & $(0.02)$ \\
ROA & $-0.18^{* * *}$ & $-0.26^{* * *}$ \\
Sales Growth & $(0.03)$ & $(0.07)$ \\
& $-0.19^{* * *}$ & $-0.16^{* * *}$ \\
Age & $(0.01)$ & $(0.04)$ \\
& $-0.004^{* * *}$ & $-0.01^{* *}$ \\
Young & $(0.001)$ & $(0.003)$ \\
& $-0.19^{* * *}$ & $-0.19^{* * *}$ \\
Old & $(0.02)$ & $(0.05)$ \\
& $0.14^{* * *}$ & $0.21^{* *}$ \\
Average Wage & $(0.22)$ & $(0.08)$ \\
& $0.79^{* * *}$ & $0.71 * * *$ \\
Focused & $(0.02)$ & $(0.05)$ \\
& $0.08^{* * *}$ & 0.04 \\
Intercept & $(0.02)$ & $(0.05)$ \\
& $-3.14 * * *$ & $-3.51^{* * *}$ \\
\hline Test of Joint Significance of Year Dummies, $\chi 2(4)$ & $(0.05)$ & $(0.47)$ \\
Test of Joint Significance of Industry Dummies, $\chi 2(33)$ & $429.23 * * *$ & $36.94 * * *$ \\
Test of Joint Significance of Region Dummies, $\chi 2(11)$ & $86.84^{* * * *}$ & $17.78^{* *} \mathrm{~b}$ \\
\hline Log-Likelihood & -71238.73 & $25.89 * * *$ \\
\hline Observations & 122272 & -6538.89 \\
\hline Notes: Clustered standard errors in parentheses; *** $(* * *)$ indicate a significance level of $1 \%(5 \%, 10 \%)$ \\
b Test of Joint Significance of Industry Dummies, $\chi 2(8)$ & & \\
& & \\
& &
\end{tabular}


Table 7: Classification of Region Dummies

\begin{tabular}{ll}
\hline Region & Description \\
\hline 1 & Groningen \\
2 & Friesland \\
3 & Drenthe \\
4 & Overijssel \\
5 & Flevoland \\
6 & Gelderland \\
7 & Utrecht \\
8 & North Holland \\
9 & South Holland \\
10 & Zeeland \\
11 & North Brabant \\
12 & Limburg \\
\hline
\end{tabular}




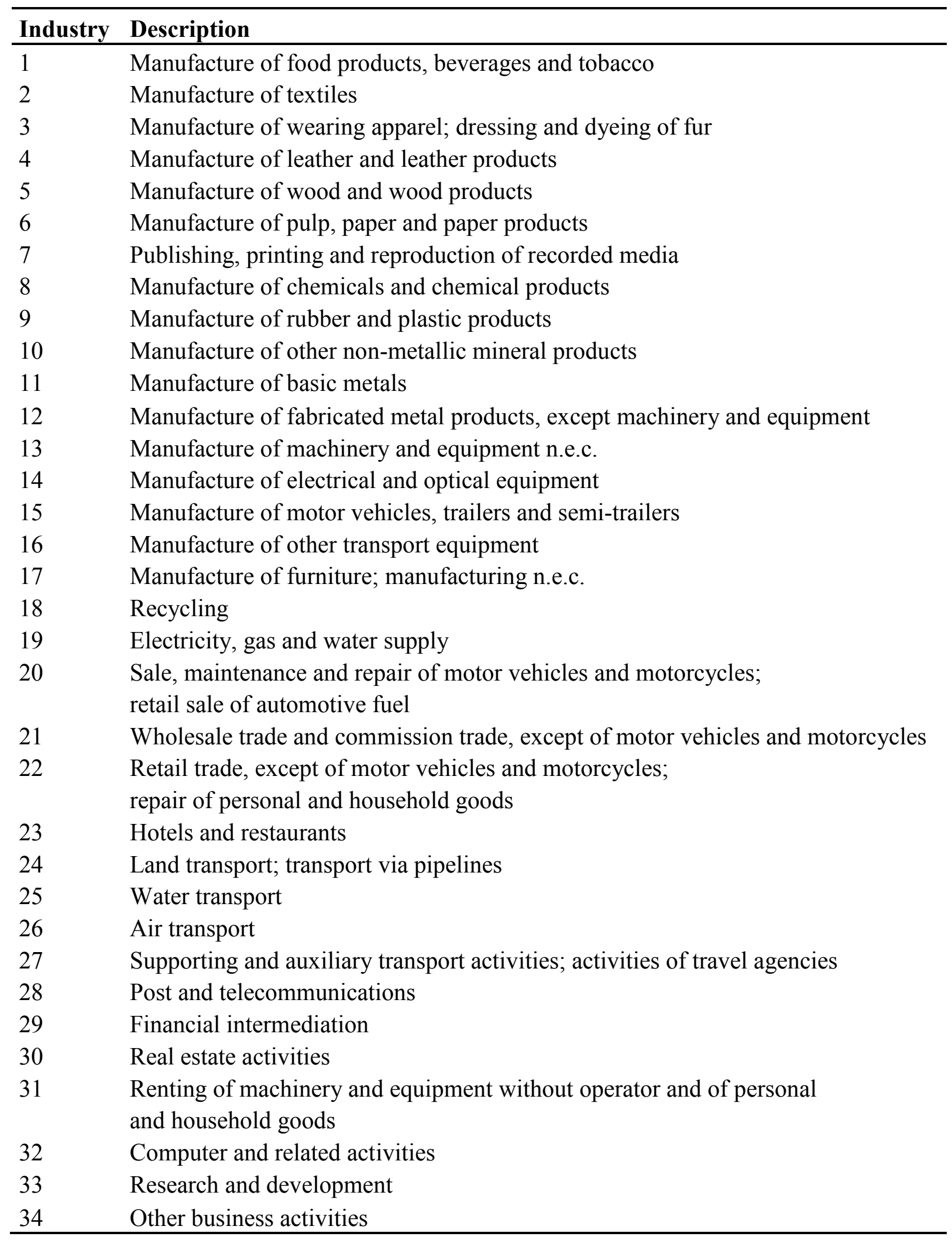

